\title{
Identification of New Candidate Pathogenicity Factors in the Xylem-Invading Pathogen Xanthomonas albilineans by Transposon Mutagenesis
}

\author{
Philippe Rott, ${ }^{1,2}$ Laura Fleites, ${ }^{2}$ Gary Marlow, ${ }^{2}$ Monique Royer, ${ }^{1}$ and Dean W. Gabriel ${ }^{2}$ \\ ${ }^{1}$ UMR BGPI, CIRAD, TA A-54/K, Campus International de Baillarguet, 34398 Montpellier Cedex 5, France; ${ }^{2}$ Department \\ of Plant Pathology, University of Florida, Gainesville 32605, U.S.A.
}

Submitted 9 July 2010. Accepted 16 December 2010.

\begin{abstract}
Xanthomonas albilineans is a xylem-invading pathogen that produces the toxin albicidin that blocks chloroplast differentiation, resulting in disease symptoms of sugarcane leaf scald. In contrast to other xanthomonads, $X$. albilineans does not possess a hypersensitive response and pathogenicity type III secretion system and does not produce xanthan gum. Albicidin is the only previously known pathogenicity factor in $X$. albilineans, yet albicidin-deficient mutant strains are still able to efficiently colonize sugarcane. To identify additional host adaptation or pathogenicity factors, sugarcane 'CP80-1743' was inoculated with 1,216 independently derived Tn5 insertions in $X$. albilineans XaFL07-1 from Florida. Sixty-one Tn5 mutants were affected in development of leaf symptoms or in stalk colonization. The Tn5 insertion sites of these mutants were determined and the interrupted genes were identified using the recently available genomic DNA sequence of $X$. albilineans GPE PC73 from Guadeloupe. Several pathogenicity-related loci that were not previously reported in Xanthomonas spp. were identified, including loci encoding hypothetical proteins, a membrane fusion protein conferring resistance to novobiocin, transport proteins, TonB-dependent outer-membrane transporters, and an OmpA family outer-membrane protein.
\end{abstract}

Xanthomonas albilineans is a gram-negative bacterium that causes leaf scald, a lethal disease of sugarcane (Rott and Davis 2000). This pathogen multiplies in the xylem and systemically colonizes the entire host plant (Champoiseau et al. 2006b; Klett and Rott 1994). It is transmitted by infected cuttings, contaminated harvesting tools, and aerial means. Disease symptoms vary from a single, white, narrow, sharply defined leaf stripe to complete wilting and necrosis of infected leaves, leading to plant death. Sugarcane leaves may also emerge with extensive white chlorosis from which the pathogen is sometimes absent. However, even if leaf scald symptoms result from changes in the chlorenchyma cells, $X$. albilineans is constrained within the xylem (Birch 2001).

Most plant-pathogenic bacteria possess a hypersensitive response and pathogenicity (Hrp) type III secretion system (T3SS) to deliver effector proteins or virulence factors from the bacterial cytoplasm into the host cell. The complete genome sequence of $X$. albilineans revealed that, in contrast to other pathogenic xanthomonads (Büttner and Bonas 2010), X. albilineans does not have an Hrp T3SS to cause disease, although it does possess an

Corresponding author: P. Rott; Telephone: +33.4.99.62.48.34; Fax: 33.4.99.62.48.48; E-mail: philippe.rott@cirad.fr animal pathogen-associated T3SS of the SPI-1 injectisome family (Pieretti et al. 2009). However, the role of this SPI-1 T3SS is unknown, and mutants in this secretion system are still able to efficiently colonize the sugarcane stalk and to cause leaf symptoms (Marguerettaz et al. 2011). Additionally, X. albilineans experienced a reductive genome evolution and is phylogenetically close to Xylella fastidiosa, another xylem-invading and xylemlimited pathogen lacking an Hrp T3SS (Pieretti et al. 2009). However, both species possess other secretion systems that could deliver virulence determinants into the plant cell or to the bacterial environment. For example, Xylella fastidiosa produces enzymes that degrade the pit membranes, allowing bacteria to move into previously uncolonized xylem vessels, most likely thanks to a type II secretion system (Perez-Donoso et al. 2010, Vojnov et al. 2010). Other virulence factors of Xylella fastidiosa and xanthomonads include motility, cell attachment by cell-surface adhesins, and formation of biofilms. Biofilms are structures that allow the bacteria to attach to a surface, and genes involved in the synthesis of pili play an important role in this adhesion process (Li et al. 2007, Vojnov et al. 2010).

In 1985, Birch and Patil first showed that a potent phytotoxin and antibiotic, called albicidin, was produced by $X$. albilineans (Birch and Patil 1985a and b). Albicidin causes foliar symptoms of leaf scald in sugarcane by inhibiting the replication of proplastic DNA and, consequently, blocking the differentiation of chloroplasts (Birch and Patil 1987a and b). On a molecular level, this toxin is a potent DNA gyrase inhibitor (Hashimi et al. 2007). Albicidin is the only previously known pathogenicity factor in $X$. albilineans, yet albicidin-deficient mutant strains are still able to efficiently colonize sugarcane (Birch 2001; Champoiseau et al. 2006a).

Variation in pathogenicity among strains of $X$. albilineans is known to occur, and published data support the possible existence of different races in Mauritius (Autrey et al. 1995). The outbreak of leaf scald in Florida in the late 1980s was closely associated with the appearance of a genetically new strain of the pathogen (Davis et al. 1997). The capacity of X. albilineans to colonize sugarcane stalks or cause symptoms varies according to the strain of the pathogen, indicating the existence of different pathotypes within the species (Champoiseau et al. 2006a; Daugrois et al. 2003; Huerta-Lara et al. 2009; Mohamed et al. 1996). High variation in pathogenicity was shown to exist in closely related strains of $X$. albilineans in Guadeloupe (Champoiseau et al. 2006b). Albicidin production in vitro varies also according to the strain of the pathogen. However, no relationship was found between the amount of albicidin produced in vitro and the pathotypes or genetic diversity of the pathogen (Renier et al. 2007). Therefore, albicidin is necessary but not sufficient 
for leaf scald development, and it appears to be one virulence factor acting coordinately with other virulence factors.

In this study, we used transposome mutagenesis to produce mutants of $X$. albilineans affected in capacity to produce foliar symptoms or to multiply and spread in the sugarcane stalk. We report the identification of new candidate pathogenicity factors in this pathogen, including some that were not previously reported in the genus Xanthomonas. Additionally, in contrast to previously reported data, we show that albicidin is not always necessary for expression of leaf scald symptoms caused by $X$. albilineans.

\section{RESULTS}

\section{Transposon mutagenesis and screening of mutants of $X$. albilineans for reduced pathogenicity.}

Following electroporation of the transposase-Tn5 DNA synaptic complexes into $X$. albilineans XaFL07-1, several thousand kanamycin-resistant colonies were obtained. The transposition efficiency was approximately 1.5 to $3 \times 10^{4} \mathrm{Tn} 5$ mutants per 20 ng of transposome. Sequence analysis of the DNA regions flanking the insertion sites in a first set of 10 mutants indicated that the transposon inserted randomly in the $X$. albilineans genome and, therefore, $\operatorname{Tn} 5$ mutants could be screened for pathogenicity. Sugarcane 'CP80-1743' was inoculated with a total of 1,216 mutants, and approximately 200 mutants were screened in each single inoculation experiment. Leaf scald symptoms were recorded on three to four emerging leaves 1 month after inoculation, and stalk colonization by the pathogen was determined 2 months after inoculation. Mutants that did not produce disease symptoms or did not efficiently colonize the sugarcane stalk were selected for a second round of plant inoculation (three to five sugarcane plants inoculated per mutant). Mutants that again caused significantly less leaf symptoms or showed reduced colonization of the sugarcane stalk compared with the wild-type strain XaFL07-1 were used to determine the insertion site of the transposon in the chromosome of $X$. albilineans.

\section{Genomic distribution and predicted products of transposon-tagged pathogenicity-related genes.}

Seventeen pathogenicity-reduced mutants carried Tn5 insertions in genes involved in the ribosome machinery (including rpsA, rRNA-5S, rRNA-16S, and rRNA-23S), and these mutants were not further investigated. Forty-four additional mutants carried insertions in 33 loci whose interruption resulted in reduced pathogenicity (Table 1 ). Single Tn5 insertions were obtained for 28 of these loci. Multiple independent insertions were obtained for five loci, including XALc_0007 (two mutants), XALc_0557 (five mutants), XALc_0624 or gene $\mathrm{fabH}$ (three mutants), XALc_2682 (two mutants), and XALc_2705 (four mutants) (Table 1). Interestingly, some pathogenicity mutants affected contiguous loci that were previously not known to be related in terms of pathogenicity function, including XALc_0885 and XALc_0886; and XALc_2704, XALc_2705, XALc_2706 (gmd), and XALc_2707 (rmd).

Pathogenicity-related loci identified in the genome of $X$. albilineans were predicted to encode proteins involved in a variety of functions, including exopolysaccharide (EPS) and lipopolysaccharide (LPS) biosynthesis (six loci), fatty acid biosynthesis (two loci), amino acid biosynthesis (one locus), purine biosynthesis (one locus), carbohydrate metabolism (one locus), nitrogen metabolism (one locus), regulatory and cell signaling (two loci), secretion systems (one locus), transport (five loci), catalytic activity (one locus), DNA binding (two loci), and drug resistance (one locus) (Table 1). In addition, nine loci were predicted to encode proteins of unknown function (Table 1).
The texture and consistency of bacterial growth on modified Wilbrink's (MW) agar medium of all mutants and the wild-type strain of $X$. albilineans were similarly slightly viscous, with the exception of mutants affected in EPS and LPS biosynthesis. The texture of colonies of these latter mutants in loci XALc_2693 (xanB), XALc_2697 (rmlB), XALc_ 2701, XALc_2705, XALc_2706 (gmd), and XALc_2707 ( $r m d)$ was dry and easily identified when bacteria were subcultured with a transfer loop, functionally confirming the predicted involvement of these loci in production of surface polysaccharides.

Mutant M564 affected locus XALc_1762 (predicted to encode a membrane fusion protein) and failed to grow on MW agar medium supplemented with cephalexin at $25 \mathrm{mg} / \mathrm{liter}$, novobiocin at $30 \mathrm{mg} / \mathrm{liter}$, cycloheximide at $50 \mathrm{mg} / \mathrm{liter}$, and benomyl at $12.5 \mathrm{mg} / \mathrm{liter}$ (WCNCB selective medium) used to isolate $X$. albilineans from plants. After further investigation, it was shown that this mutant was unable to grow on MW medium supplemented with novobiocin at $5 \mathrm{mg} / \mathrm{liter}$ whereas the wild-type strain was able to grow on MW medium supplemented with novobiocin at up to $60 \mathrm{mg} / \mathrm{liter}$.

Pathogenicity-related loci encoding hypothetical proteins with unknown functions were scattered across the chromosome of X. albilineans. XALc_0007 is located near the start of chromosome replication and upstream of three biopolymer transport proteins encoded by exbB, exbD1, and exbD2. Orthologs of XALc_0007 exist in all bacterial species belonging to the Xanthomonadaceae family.

XALc_0639 is located downstream of prpB, encoding a methylisocitrate lyase, and upstream of $\operatorname{prp} C$, encoding a 2methylcitrate synthase, suggesting that XALc_0639 is involved in citrate metabolism. Interestingly, this locus has only been reported previously in the genome of $X$. axonopodis pv. vasculorum (the causal agent of gumming of sugarcane) and $X$. vasicola pv. musacearum (the causal agent of banana bacterial wilt), two xylem-invading pathogens.

XALc_0742 is located upstream of genes waaG and waaL and in the same gene cluster as waaM and waaA, which are all involved in LPS biosynthesis. Therefore, XALc_0742 may also be involved in LPS production. Orthologous genes of XALc_0742 exist in all bacterial species belonging to the Xanthomonadaceae family. Mutations in XALc_0742 are expected to have a polar effect on downstream genes because it is the first open reading frame (ORF) of the gene operon.

Genes surrounding XALc_0885, XALc_0886, XALc_2347, and XALc_2682 did not give any relevant clues regarding a possible function for these loci. However, no orthologs of XALc_0885 were found in any other bacterial species and only one was found for XALc_0886 in the genome of X. axonopodis pv. vasculorum, suggesting that these two contiguous loci are specific for interactions with sugarcane. Orthologs of XALc_2347 exist in all sequenced xanthomonads and in Stenotrophomonas spp. but not in Xylella fastidiosa, which is missing the entire XALc_2343 to XALc_2348 operon. Orthologs of XALc_2682 exist in all bacterial species belonging to the Xanthomonadaceae family.

XALc_2704 is located in a gene region involved in biosynthesis of cell surface polysaccharides, including XALc_2701, XALc_2702, XALc_2705, and XALc_2706. Orthologs of XALc_2705 and XALc_2706 in X. campestris pv. campestris (XC3630 and XC3627, respectively) were reported as pathogenicity-related genes (Qian et al. 2005) (Table 1). XALc_2704 might encode a protein with a similar function, although the mutant in this ORF (M694) did not show any obvious difference in texture and consistency compared with the wild-type strain. Interestingly, this locus was not found in any other bacterial species. XALc_2704 is the last ORF of the operon and 
Table 1. Transposon mutants of Xanthomonas albilineans affected in pathogenicity

\begin{tabular}{|c|c|c|c|c|c|c|c|}
\hline \multirow[b]{2}{*}{ Mutant } & \multirow[b]{2}{*}{ Locus $^{w}$} & \multirow[b]{2}{*}{ PR gene ${ }^{x}$} & \multirow[b]{2}{*}{ Functional category $^{y}$} & \multirow[b]{2}{*}{ Predicted product $^{\mathrm{z}}$} & \multirow[b]{2}{*}{ Gene } & \multicolumn{2}{|c|}{ Pathogenicity $^{\mathrm{v}}$} \\
\hline & & & & & & DS & ESC \\
\hline M655 & XALc_0007 & $\ldots$ & Function unknown & Conserved hypothetical protein & $\ldots$ & ++ & ++ \\
\hline M1133 & XALc 0007 & $\ldots$ & Function unknown & Conserved hypothetical protein & $\ldots$ & - & + \\
\hline M516 & XALc_0028 & $\ldots$ & Transport & $\mathrm{ABC}$ transporter permease & $\ldots$ & - & - \\
\hline M791 & XALc_0297 (1) & $\ldots$ & $\begin{array}{l}\text { Regulatory and cell } \\
\text { signaling }\end{array}$ & $\begin{array}{l}\text { Two component system sensor response } \\
\text { regulator hybrid protein }\end{array}$ & $\ldots$ & +++ & ++ \\
\hline M227 & XALc_0557 & $\ldots$ & Function unknown & OmpA-family protein & $\ldots$ & - & + \\
\hline M468 & XALc_0557 & $\ldots$ & Function unknown & OmpA-family protein & $\ldots$ & _- & - \\
\hline M573 & XALc_0557 & $\ldots$ & Function unknown & OmpA-family protein & $\ldots$ & - & - \\
\hline M768 & XALc_0557 & $\ldots$ & Function unknown & OmpA-family protein & $\ldots$ & - & +++ \\
\hline M1152 & XALc_0557 & $\ldots$ & Function unknown & OmpA-family protein & $\ldots$ & - & - \\
\hline M352 & XALc_0567 & $\ldots$ & Purine biosynthesis & Amidophosphoribosyltransferase & purF & - & - \\
\hline M510 & $\begin{array}{l}\text { Intergenic region } \\
\text { upstream of } \\
\text { XALc_0590 }\end{array}$ & & DNA binding & $\begin{array}{l}\text { DNA-binding protein } \mathrm{HU} \text { (histone-like protein } \\
\text { HU) }\end{array}$ & hирB & + & ++ \\
\hline M73 & XALc_0624 & $\begin{array}{l}\text { XOO0878 (Xoo), } \\
\text { XOCORF_1172 } \\
\text { (Xoc) }\end{array}$ & Fatty acid biosynthesis & 3-oxoacyl-(acyl-carrier-protein) synthase 3 & $\mathrm{fabH}$ & - & +++ \\
\hline M550 & XALc_0624 & $\begin{array}{l}\text { XOO0878 (Xoo), } \\
\text { XOCORF_1172 } \\
\text { (Xoc) }\end{array}$ & Fatty acid biosynthesis & 3-oxoacyl-(acyl-carrier-protein) synthase 3 & $\mathrm{fabH}$ & + & ++ \\
\hline M770 & XALc_0624 & $\begin{array}{l}\text { XOO0878 (Xoo) } \\
\text { XOCORF_1172 } \\
\text { (Xoc) }\end{array}$ & Fatty acid biosynthesis & 3-oxoacyl-(acyl-carrier & $\mathrm{fabH}$ & + & +++ \\
\hline M74 & XALc_0639 (2) & $\ldots$ & Function unknown & Hypothetical protein & $\ldots$ & ++ & +++ \\
\hline M75 & XALc_0643 (1) & $\ldots$ & Transport & TonB-dependent outer-membrane transporter & $\ldots$ & + & +++ \\
\hline M697 & XALc_0723 (1) & $\ldots$ & Transport & TonB-dependent outer-membrane transporter & $\ldots$ & + & + \\
\hline M1019 & XALc_0739 & $\ldots$ & Carbohydrate metabolism & NADP dependent malic enzyme & maeB & + & + \\
\hline M1127 & XALc_0742 & $\ldots$ & Function unknown & Hypothetical protein & $\ldots$ & + & + \\
\hline M676 & XALc_0885 (4) & $\ldots$ & Function unknown & Hypothetical protein & $\ldots$ & ++ & +++ \\
\hline M79 & XALc $0886(3)$ & $\ldots$ & Function unknown & Transmembrane hypothetical protein & $\ldots$ & + & ++ \\
\hline M1162 & XALc_0911 & $\ldots$ & Fatty acid biosynthesis & Acyl-CoA thioesterase II & tes $B$ & +++ & +++ \\
\hline M375 & XALc 1042 & $\ldots$ & DNA binding & Single-stranded DNA-binding protein & $s s b$ & - & + \\
\hline M39 & XALc_1068 & $\ldots$ & Catalytic activity & Dipeptidyl peptidase precursor & $\ldots$ & ++ & ++ \\
\hline M1009 & XALc_1434 (1) & $\ldots$ & $\begin{array}{l}\text { Regulatory and cell } \\
\text { signaling }\end{array}$ & $\begin{array}{l}\text { Two component system sensor response } \\
\text { regulator hybrid protein }\end{array}$ & 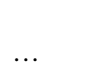 & +++ & ++ \\
\hline M564 & XALc_1762 & $\ldots$ & Drug resistance & $\begin{array}{l}\text { Membrane fusion protein (confers resistance to } \\
\text { novobiocin) }\end{array}$ & & ++ & +++ \\
\hline M388 & XALc_2347 (1) & $\ldots$ & Func & Hypothetical protein & $\ldots$ & + & + \\
\hline M139 & XALc_2426 & & Transport & Biopolymer transport TolQ protein & tolQ & - & ++++ \\
\hline M326 & XALc_2656 & XC3565 (Xcc) & Secretion systems & General secretion pathway protein $\mathrm{M}$ & $x p s M$ & _- & + \\
\hline M624 & XALc_2682 & $\ldots$ & Function unknown & $\begin{array}{l}\text { Conserved hypothetical protein with conserved } \\
\text { region DUF1212 (putative membrane } \\
\text { protein) }\end{array}$ & $\ldots$ & - & +++ \\
\hline M1190 & XALc_2682 & $\ldots$ & Function unknown & $\begin{array}{l}\text { Conserved hypothetical protein with conserved } \\
\text { region DUF1212 (putative membrane } \\
\text { protein) }\end{array}$ & $\ldots$ & ++++ & +++ \\
\hline M427 & XALc_2693 & ХOO0796 (Хоo) & EPS and LPS biosynthesis & Mannose-6-phosphate isomerase & $x a n B$ & _- & - \\
\hline M51 & XALc_2697 & $\ldots$ & EPS and LPS biosynthesis & dTDP-glucose 4,6-dehydratase & $r m l B$ & + & +++ \\
\hline M820 & XALc $2701(4)$ & $\ldots$ & EPS and LPS biosynthesis & Glycosyl transferase & $\ldots$ & +++ & ++ \\
\hline M694 & XALc_2704 (4) & $\ldots$ & Function unknown & Conserved hypothetical protein & $\ldots$ & ++ & ++ \\
\hline M374 & XALc_2705 (5) & XC3630 (Xcc) & EPS and LPS biosynthesis & Glycosyl transferase & $\ldots$ & - & - \\
\hline M416 & XALc_2705 (5) & XC3630 (Xcc) & EPS and LPS biosynthesis & Glycosyl transferase & $\ldots$ & + & + \\
\hline M631 & XALc_2705 (5) & XC3630 (Xcc) & EPS and LPS biosynthesis & Glycosyl transferase & $\ldots$ & + & + \\
\hline M903 & XALc_2705 (5) & XC3630 (Xcc) & EPS and LPS biosynthesis & Glycosyl transferase & $\ldots$ & + & + \\
\hline M967 & XALc_2706 (5) & XC3627 (Xcc) & EPS and LPS biosynthesis & GDP-mannose 4,6-dehydratase & gmd & ++ & +++ \\
\hline M1116 & XALc_2707 (5) & $\ldots$ & EPS and LPS biosynthesis & NDP-hexose oxidoreductase & rmd & - & - \\
\hline M67 & XALc_2843 & XOO3860 (Xоo) & Amino acid biosynthesis & Glycine/serine hydroxymethyltransferase & glyA & + & ++++ \\
\hline M61 & XALc_2974 (1,5) & ... & Transport & Magnesium and cobalt transport protein & $\operatorname{cor} A$ & ++ & ++ \\
\hline M9 & XALc_3092 & $\ldots$ & Nitrogen metabolism & Nitrogen regulatory protein P-II & $g \ln B 1$ & +++ & +++ \\
\hline
\end{tabular}

${ }^{v}$ Pathogenicity in sugarcane is rated as disease severity (DS) and extent of stalk colonization (ESC) compared with wild-type disease severity and stalk colonization, respectively. Symbols: $-=0$ to $10 \%,+=11$ to $30 \% ;++=31$ to $50 \%,+++=51$ to $70 \%$, and $++++=71$ to $95 \%$. DS and ESC were calculated with data obtained for 9 to 15 leaves and 3 to 5 stalks, respectively.

${ }^{\text {w }}$ Based on the genome sequence of X. albilineans GPE PC73 (Pieretti et al. 2009). Orthologous genes of these loci exist in all sequenced species of the Xanthomonadaceae family (Stenotrophomonas, Xanthomonas, and Xylella) with the exception of (1) locus not present in Xylella fastidiosa, (2) $=10 c u s$ present only in Xanthomonas albilineans, $X$. axonopodis pv. vasculorum, and X. vasicola pv. musacearum, $(3)=$ locus present only in $X$. albilineans and $X$. axonopodis pv. vasculorum, (4) locus present only in X. albilineans, and (5) = locus not present in Stenotrophomonas maltophilia.

${ }^{\mathrm{x}}$ Pathogenicity-related $(\mathrm{PR})$ orthologous genes: Xcc $=$ X. campestris pv. campestris 8004 (Qian et al. 2005), Xoo = X. oryzae pv. oryzae KACC10331 (Wang et al. 2008), Xoc $=$ X. oryzae pv. oryzicola BLS303 (Wang et al. 2007).

${ }^{\mathrm{y}}$ EPS $=$ exopolysaccharide and LPS = lipopolysaccharide.

${ }^{\mathrm{z}}$ OmpA $=$ outer-membrane protein A. 
mutations in this locus should not result in polar effects on downstream genes.

\section{An outer-membrane protein is required}

for both disease-symptom expression and

sugarcane stalk colonization by $X$. albilineans.

Five independent Tn5 insertions that produced few or no leaf disease symptoms were located in XALc_0557 (Fig. 1), which is predicted to encode an OmpA family outer-membrane protein that was named XaOmpA1. A putative Shine-Dalgarno sequence was identified upstream of the start codon and, at least in the genome of sequenced strain $X$. albilineans GPE PC73, XALc_0557 is preceded by XALc_0556 in the opposite orientation on the complementary DNA strand (Pieretti et al. 2009). Additionally, XALc_0557 is followed by a predicted Rho-independent terminator, indicating that this locus is not

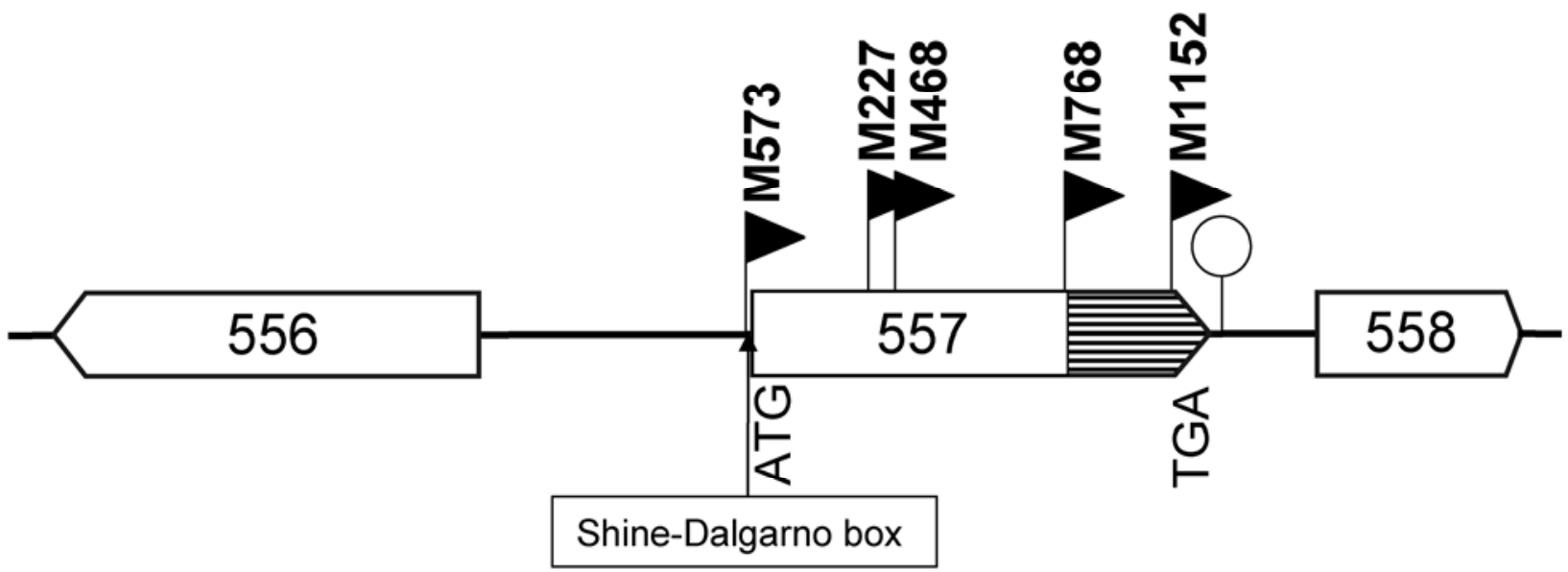

Fig. 1. Distribution of single-transposon insertion mutants showing reduced pathogenicity phenotype in locus XALc_0557 (1,101 bp) of Xanthomonas albilineans XaFL07-1. The striped area at the $3^{\prime}$ end of the coding sequence of XALc_0557 (= 557) encodes the OmpA domain. Position of the insertion site in each mutant is indicated by a flag. Mutant identification numbers are indicated on top of each flag. The loop downstream of the locus represents a predicted Rho-independent terminator. Locus XALc_0556 (= 556) located upstream of XALc_0557 is predicted to encode an oxidoreductase. Locus XALc_0558 (=558) located downstream of XALc_0557 is predicted to encode a conserved hypothetical protein.
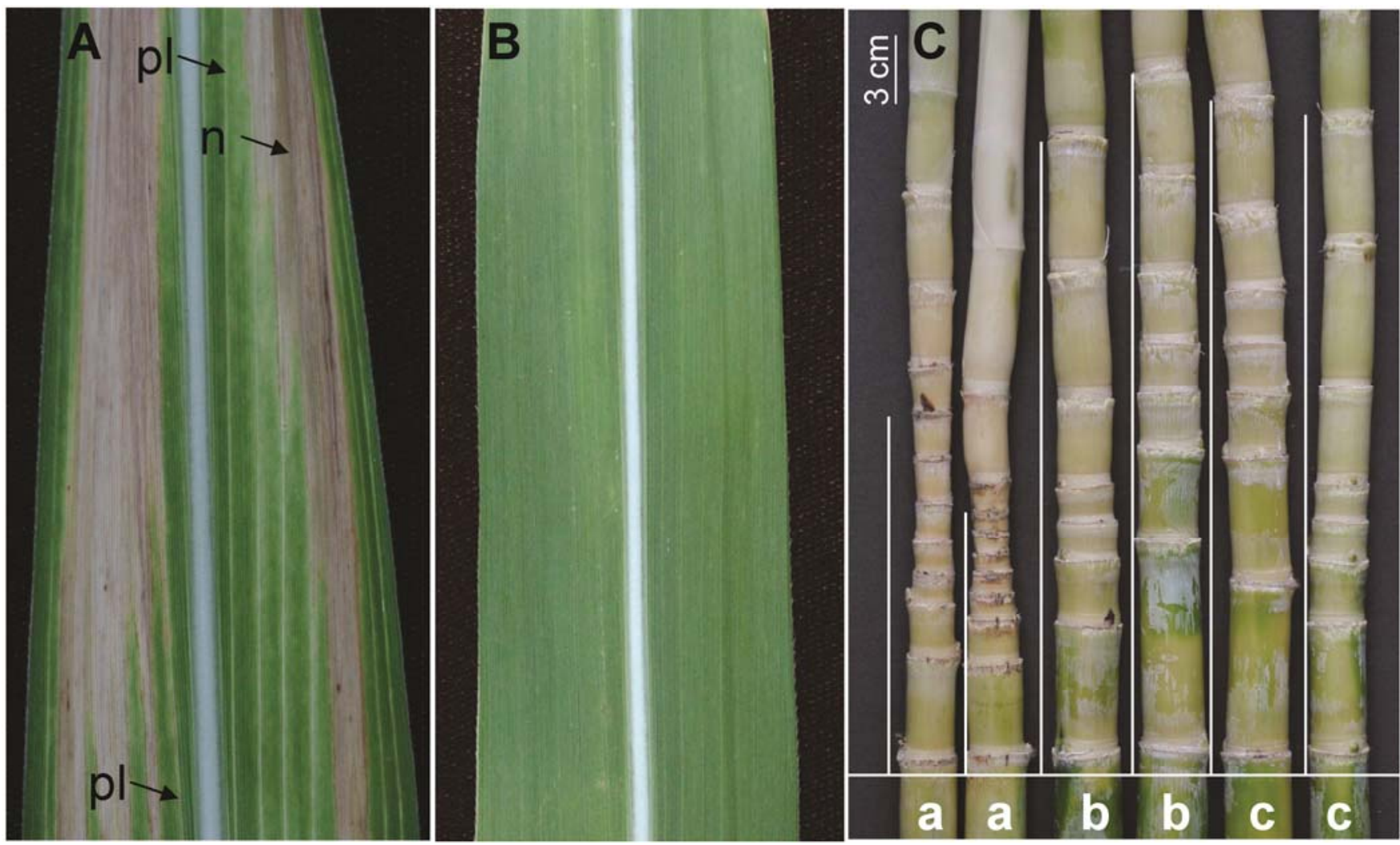

Fig. 2. Leaf scald symptoms caused by Xanthomonas albilineans after inoculation of sugarcane 'CP80-1743'. A, Pencil-line stripes (pl) and necrosis (n) produced by wild-type XaFL07-1 1 month after plant inoculation. B, Symptomless leaf inoculated with XaOmpA1-mutant M227 1 month after inoculation. C, Effect of $X$. albilineans XaFL07-1 and XaOmpA1-mutant M227 on growth of stalks of sugarcane 'CP80-1743' 2 months after plant inoculation. Stalks labeled a, b, and c were inoculated with XaFL07-1, distilled water, and mutant M227, respectively. White vertical bars represent growth size of seven internodes after inoculation and removal of leaves. 
part of an operon and that transposon insertions in XALc_0557 should not result in polar effects on downstream genes.

All XaOmpA1-mutants of $X$. albilineans produced albicidin in amounts equivalent to the wild type in vitro but produced no or very few pencil line stripes on sugarcane leaves (Fig. 2A and B). Additionally, although leaves inoculated with XaOmpA1-mutant M227 were symptomless, the pathogen was present in these leaves, from which it was easily reisolated on MW medium (data not shown). In separate experiments, mean disease severity (DS) of the five mutants varied between 0 and 0.4 (on a 0-to-6 scale), whereas mean DS of the wild-type strain of $X$. albilineans was between 4.0 and 5.6. Mean extent of stalk colonization (ESC) varied between 0 and 14 (on a 0to-100 scale) for mutants M227, M468, M573, and M1152, whereas mean ESC of the wild-type strain of $X$. albilineans was between 76 and 98. In one experiment, mutant M768 colonized a greater length of the sugarcane stalk than the other mutants (mean ESC $=60$ ) but population densities of this mutant were lower than those of the wild-type strain (mean ESC = 98). When growth of sugarcane stalks was measured 2 months after inoculation with i) wild-type XAFL07-1, ii) distilled water (control), and iii) mutant M227, only the wild-type strain affected stalk size (Fig. 2C). The growth rate of all XaOmpA1mutants in liquid MW medium and in liquid minimal medium was lower than the growth rate of wild-type $X$. albilineans (Fig. 3; data not shown). Although XaOmpA1-mutants grew more slowly and reached lower population sizes than the wildtype strain in both media (Fig. 3), XaOmpA1-mutants were able to reach high population densities (optical density at 600 $\mathrm{nm}\left[\mathrm{OD}_{600}\right]$ of 0.25 to $\left.0.30=10^{9} \mathrm{CFU} / \mathrm{ml}\right)$. All mutants except mutant M768 were also less motile than the wild-type strain in MW $0.25 \%$ agar medium (Fig. 4).

XALc_0557 showed 81 to $83 \%$ amino acid identity to orthologous loci in other Xanthomonas spp. (Table 2). This identity was also very high in other members of the Xanthomonadaceae family: $78 \%$ with two strains of Stenotrophomonas maltophilia and $68 \%$ with two strains of Xylella fastidiosa. Surprisingly, locus XALc_0557 showed high amino acid identity (68\%) to an ompA locus of Clostridium sp. strain M62/1. With the exception of the Clostridium sp., these identity values are similar to those observed with housekeeping genes such as gyrB (Table 2), suggesting that locus XALc_0557 is highly conserved among species of the Xanthomonadaceae family and under purifying selection. Only the ompA domain of the protein showed some identity (37 to 40\%) with proteins encoded by the xylem-invading plant pathogen Ralstonia solanacearum (strain GMI1000) and the human pathogen Escherichia coli (strain K-12 substrain MG1655), confirming that locus XALc_0557 is specific to members of Xanthomonadaceae.

\section{Pathogenicity of albicidin-deficient mutant isolates.}

Albicidin is a small molecule synthesized by a unique, large, and mixed polyketide synthase-nonribosomal peptide synthetase (NRPS) gene cluster (Royer et al. 2004). Surprisingly, no Tn5 insertions were found in any of the albicidin biosynthesis genes, despite the fact that they cover approximately $1.4 \%$ of the $X$. albilineans genome. Therefore, we produced five sitespecific deletion mutant isolates of $a l b X X I(=x a b A)$, a gene which encodes a phosphopantetheinyl transferase, an enzyme involved in post-translational activation of NRPS and required for albicidin biosynthesis (Huang et al. 2000; Royer et al. 2004). Polymerase chain reaction (PCR) and albicidin assays confirmed that albXXI was deleted in $\triangle a l b X X I$ mutant isolates of XaFL07-1 and that these isolates do not produce any detectable albicidin in vitro (data not shown).

In the first greenhouse experiment, sugarcane 'CP80-1743' was inoculated with XaFL07-1 and the five $\triangle a l b X X I$ mutant isolates of XaFL07-1 (eight plants were inoculated with the wild-type strain at $10^{9} \mathrm{CFU} / \mathrm{ml}$ and four plants were inoculated per mutant isolate at $10^{9} \mathrm{CFU} / \mathrm{ml}$ ). Within 10 days to 3 weeks, the wild-type strain and also all five mutant isolates produced leaf scald symptoms on inoculated leaves, including pencil line stripes, yellow chlorosis, and necrosis (Fig. 5). However, pencil line stripes produced by the albicidin-deficient mutant isolates were not as wide as those usually produced by XaFL07-1 (0.1 versus 0.2 to $0.3 \mathrm{~mm}$ ). These pencil lines were also more diffuse and yellowish or red in color whereas those usually produced by XaFL07-1 were well defined and generally white in color. Pathogen population densities in leaves were similar for the wild type (mean of $1.8 \times 10^{9} \mathrm{CFU} / \mathrm{g}$ of fresh matter determined with 5 leaf samples) and for albicidindefective mutant isolates (mean of $1.0 \times 10^{9} \mathrm{CFU} / \mathrm{g}$ of fresh matter determined with 10 leaf samples). More than 1,500 CFU of $\triangle a l b X X I$ mutant isolates were tested for albicidin production after isolation from symptomatic leaves, and all tested negative. In contrast, the 1,000 CFU of XaFL07-1 isolated from symptomatic leaves all produced albicidin in vitro. The pathogen was also successfully reisolated from internodes of the 8 stalks inoculated with XaFL07-1 and from the 20 stalks inoculated with the mutant isolates.

In a second greenhouse experiment, sugarcane 'CP80-1743' was inoculated with XaFL07-1 and mutant $\triangle a l b X X I$ isolate M8 at three different inoculum concentrations (six plants were inoculated per strain and per inoculum concentration: $10^{9}, 10^{8}$, and $\left.10^{7} \mathrm{CFU} / \mathrm{ml}\right)$. As in the first experiment, XaFL07-1 and the albicidin-deficient mutant induced leaf scald symptoms as described in the first experiment, within 10 days and 3 weeks. DS observed on leaves that developed after inoculation and extent of stalk colonization by the pathogen were not different between the wild-type strain and the albicidin-deficient mutant at all inoculum concentration used (Table 3). Additionally, mutant $\triangle a l b X X I$ isolate M8 affected sugarcane growth (reduced size of internodes) similarly to XaFL07-1 (Fig. 5). However, the population size of the albicidin-deficient mutant at stalk internode +6 was significantly lower than the population size of the wild-type strain at the same location: $2.0 \times 10^{6} \mathrm{CFU}$ per gram of fresh matter versus $1.0 \times 10^{7} \mathrm{CFU}$ per gram of fresh matter. More than 1,000 CFU of $\triangle a l b X X I$ isolate M8 were tested for albicidin production after isolation from inoculated stalks, and all tested negative.

\section{DISCUSSION}

A simple mutagenesis system based on a transposon-transposase synaptic complex (transposome) proved to be very efficient in producing $\mathrm{Tn} 5$ transposon mutants of $X$. albilineans. As previously shown in other bacterial species (Guihabert et al. 2001; Wang et al. 2008), transpositions occurred at generally random sites on the $X$. albilineans chromosome. However, identification of several transposon insertions in a few loci also suggests that the transposon insertion sites are not absolutely random. The genome size of $X$. albilineans is approximately 3.8 Mb (Pieretti et al. 2009) and a screen of only 1,216 mutants does not begin to approach a saturation scale ( 1 insertion per average-size gene of 1,000 bp). Nevertheless, the approach was useful for the identification of new candidate pathogenicity factors in X. albilineans, which is a unique species of Xanthomonas. Surprisingly, a high frequency $(2.7 \%)$ of nonredundant pathogenicity-affected mutants was obtained (ribosomal mutants excluded), whereas only $0.45,0.3$, and $0.2 \%$ mutants were impaired in virulence in a large-scale screening of $X$. campestris pv. campestris (Qian et al. 2005), X. oryzae pv. oryzae (Wang et al. 2008), and X. oryzae pv. oryzicola (Wang et al. 2007), respectively. It is possible that pathogenicity-related 
genes are present as a higher percentage of the total in the reduced genome of $X$. albilineans.

The $X$. albilineans genome encodes 12 large nonhomologous NRPS in six regions, and these NRPS are activated by a specific phosphopantetheinyl transferase encoded by albXXI. In all, 3 of the 12 NRPS of $X$. albilineans, encoded in the same gene cluster called XALB1, were previously described as involved in albicidin biosynthesis (Royer et al. 2004). The products encoded by the nine other NRPS are currently unknown. Surprisingly, we did not identify any Tn5 mutants affected in albicidin biosynthesis. Furthermore, and in contrast to expected results (Birch 2001), albicidin-deficient mutant isolates produced by deletion mutagenesis were still able to produce disease symptoms such as necrosis, resulting in partial or total leaf death. Use of different strains of the pathogen, different sugarcane cultivars, or different environmental conditions affecting symptom expression may explain this conflicting result. Regardless, one implication of these results is that the antipathogenesis approach to control leaf scald disease, based on specific degradation of albicidin (Birch 2001), may not be effective with all strains of $X$. albilineans or under all environmental conditions.

Although albicidin-deficient mutant M8 of strain XaFL07-1 was able to spread efficiently in the leaf and the stalk xylem, its population densities in the upper part of the stalk (internode +6 ) were slightly lower than those of wild-type strain XaFL07-1. Therefore, albicidin may only contribute to full pathogenicity of at least some strains of $X$. albilineans. Other molecules encoded by NRPS may also contribute to full pathogenicity of $X$. albilineans. Mutagenesis and complementation studies of multiple NRPS genes will be necessary to investigate this hypothesis.

Xanthan gum produced by Xanthomonas spp. is an EPS widely used in the food, cosmetic, and oil industries as a thick- ening agent. It contributes to Xanthomonas spp. epiphytic survival (Dunger et al. 2007) and also to pathogenicity of $X$. axonopodis pv. citri, the causal agent of citrus canker (Rigano et al. 2007). Although $X$. albilineans does not produce xanthan gum and is not a slime-former on sucrose-rich media, polysaccharides are present on its cell surface, as evidenced by slightly viscous cultures that become dry when genes involved in EPS or LPS production are mutated. Surface polysaccharides, including EPS and LPS, represent the predominant structures on all bacterial surfaces, and they are often important players in plant-pathogen interactions. LPS is increasingly recognized as a major pathogen-associated molecular pattern factor (Jackson 2009; Patil et al. 2007). Mutants of $X$. albilineans affected in production of surface polysaccharides were not only affected in symptom production but also in capacity to spread in the sugarcane stalk xylem. The transposon insertion site of mutant M51 was found to be located in gene $r m l B$ that is predicted to encode a dTDP-glucose 4,6-dehydratase. This enzyme is known to be involved in LPS biosynthesis (Patil et al. 2007). The LPS provides a critical protection function against plant defenses (Kingsley et al. 1993); therefore, this result may be expected. To our knowledge, this is the first report of a critical role of $r m l B$ in plant pathology.

Similarly, several other loci that are pathogenicity related in $X$. albilineans have not been reported thus far as encoding pathogenicity factors in other Xanthomonas spp. These include proteins with unknown functions, a membrane-fusion protein conferring resistance to novobiocin, and transport proteins (tolQ, corA, and TonB-dependent outer-membrane transporters [TBDT]). TonB-dependent transport is a mechanism for active uptake across the outer membrane of gram-negative bacteria (Schauer et al. 2008). TBDT are outer-membrane proteins known for the active transport of iron complexes and vitamin

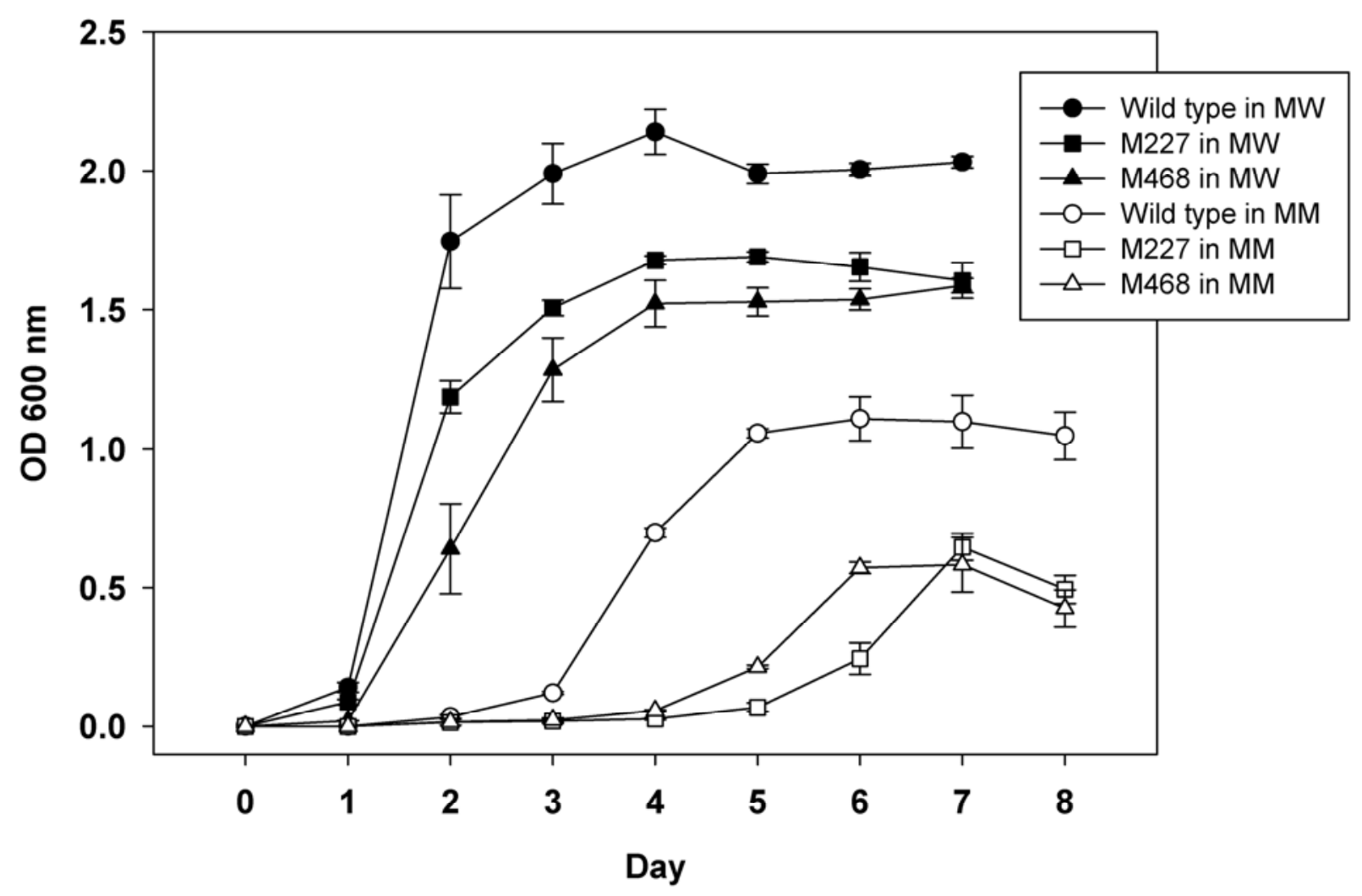

Fig. 3. Growth of Xanthomonas albilineans XaFL07-1 (wild type) and XaOmpA1-mutants M227 and M468 in modified Wilbrink's (MW) liquid medium and in liquid minimal medium (MM). Growth measured for 7 to 8 days after inoculation of each medium is expressed as optical density at $600 \mathrm{~nm}\left(\mathrm{OD}_{600}\right)$, and each point represents the mean of four different tubes per strain. Bars represent standard deviation. 
$\mathrm{B}_{12}$, and also nickel and different carbohydrates. In $X$. campestris pv. campestris, one TBDT transports sucrose with a very high affinity, suggesting that it might be a sucrose scavenger, and mutants in the corresponding gene are affected in pathogenicity (Blanvillain et al. 2007). Therefore, TBDT also may play a role in bacterial adaptation to plants, involving scavenging plant carbohydrates (Blanvillain et al. 2007; Jackson 2009; Schauer et al. 2008). TBDT are overrepresented in Xanthomonas spp. (Blanvillain et al. 2007) and 35 TBDT loci were identified in the genome of $X$. albilineans (E. Lauber, unpublished data). Orthologous genes of the two pathogenicity-related TBDT of $X$. albilineans exist in other pathogenic xanthomonads but they have not been associated with pathogenicity thus far.

Most of the pathogenicity-related genes identified herein will require confirmation by genetic complementation because observed phenotypes may also be due to spontaneous ectopic mutations or to polar effects of insertions on downstream genes. However, isolation of three, four, and five independent mutations in loci fabH (3-oxoacyl-[acyl-carrier-protein] synthase 3), XALc_2705 (glycosyl transferase), and XALc_0557 (XaOmpA1), respectively, strongly support the conclusion that these loci are relevant pathogenicity factors in $X$. albilineans. Additionally, locus XALc_2705 is located next to two other genes ( $g m d$ and $r m d$ ) involved in LPS synthesis and for which each independent mutation resulted in loss of pathogenicity, strongly supporting their role in pathogenicity. Furthermore, several genes identified herein, such as $f a b H, g l y A$, or $x a n B$ are orthologues of genes involved in pathogenicity of other related bacterial pathogens.
The transposon insertion site of five independent mutants (M227, M468, M573, M768, and M1152) was found to be located in locus XALc_0557 which is predicted to encode an outer-membrane protein (XaOmpA1). Transposon insertions in this locus resulted in mutants of $X$. albilineans that were greatly affected in pathogenicity. These mutants could no longer produce leaf symptoms or efficiently spread in the stalk xylem. OmpA proteins play an essential role in virulence of several human pathogens (Ristow et al. 2007; Singamsetty et al. 2008; Smith et al. 2007; Wang and Kim 2002). Although orthologous genes showing high protein identity to $X$. albilineans XALc_0557 exist in other species of Xanthomonadaceae, and extensive transposon mutagenesis was performed in model species such as $X$. campestris pv. campestris (Qian et al. 2005) and $X$. oryzae pv. oryzae (Wang et al. 2008), this particular OmpA-family protein, thus far, has not been suspected of involvement in symptom development and spread in xylem vessels by a bacterial plant pathogen. A second OmpA-family protein (XC4223 or XCC4132) also exists in X. albilineans (XALc_0045) and was found to be essential for symptom expression in $X$. campestris pv. campestris but its function is unknown (Qian et al. 2005). Similarly, an OmpA mutant showing reduced symptom expression was reported in $X$. oryzae pv. oryzae (Wang et al. 2008) but this locus does not show homology to locus XALc_0557 of X. albilineans.

An XALc_0557 homolog, MopB, was suspected to be involved in xylem adhesion and pathogenicity of Xylella fastidiosa but this suspicion was not confirmed (Bruening et al. 2004). However, because X. albilineans and Xylella fastidiosa
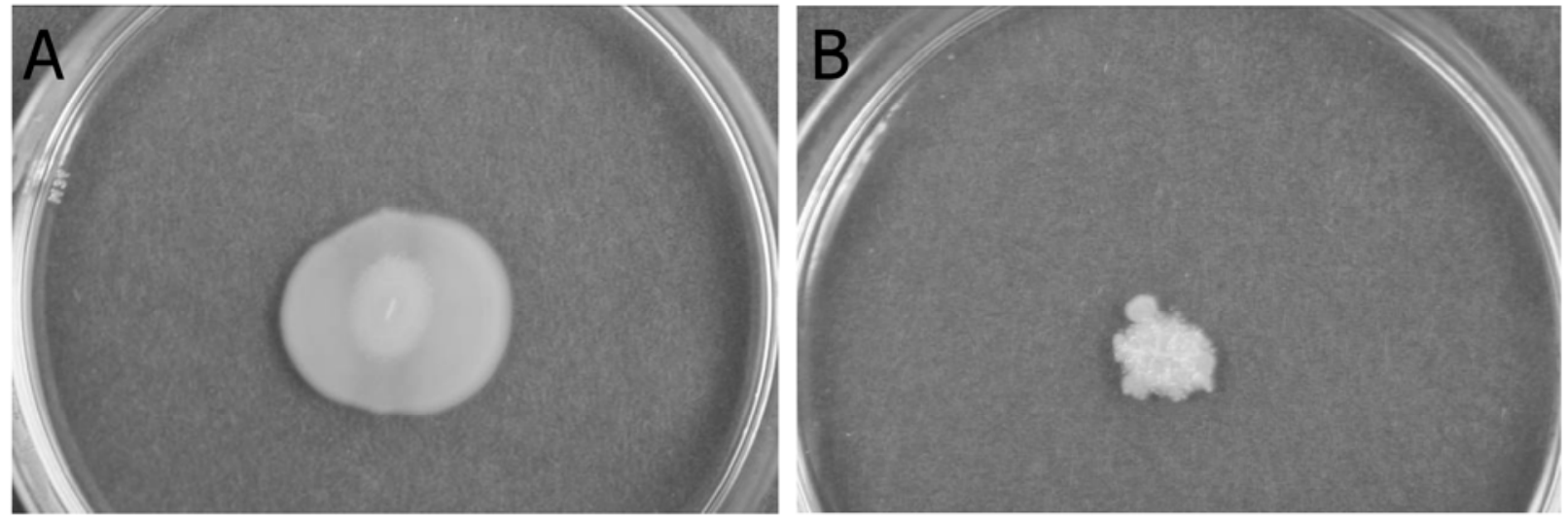

Fig. 4. Motility of Xanthomonas albilineans A, XaFL07-1 and B, XaOmpA1-mutant M227 in modified Wilbrink's 0.25\% agar medium. Bacteria in the white halo in $\mathrm{A}$ are $X$. albilineans. Picture was taken 11 days after stab inoculation of the medium.

Table 2. Amino acid identity of ompA locus (XALc_0557) and housekeeping gene gyrB (XALc_0004) of Xanthomonas albilineans to orthologous loci in other bacterial species ${ }^{\mathrm{y}}$

\begin{tabular}{|c|c|c|c|c|c|c|}
\hline \multirow[b]{2}{*}{ Taxon } & \multicolumn{3}{|c|}{ XALc_0557 ompA (366 aa) } & \multicolumn{3}{|c|}{ gyr B = XALc_0004 (820 aa) } \\
\hline & Ortholog & Length (aa) & Identity $^{\mathbf{z}}$ & Ortholog & Length (aa) & Identity $^{\mathbf{z}}$ \\
\hline X. oryzae pv. oryzae MAFF 311018 & XOO_3490 & 365 & $306 / 366(83 \%)$ & XOO_0004 & 814 & $701 / 821(85 \%)$ \\
\hline X. axonopodis pv. citri 306 & XAC1012 & 365 & $302 / 366(82 \%)$ & XАC0004 & 814 & $702 / 821(85 \%)$ \\
\hline X. campestris pv. vesicatoria $85-10$ & XCV1042 & 365 & $302 / 366(82 \%)$ & XCV0004 & 832 & $702 / 821(85 \%)$ \\
\hline X. campestris pv. campestris ATCC 33913 & XCC0935 & 365 & $299 / 366(81 \%)$ & XCC0004 & 814 & $707 / 821(86 \%)$ \\
\hline Stenotrophomonas maltophilia K279a & Smlt0955 & 366 & $293 / 371(78 \%)$ & Smlt0005 & 819 & $706 / 820(86 \%)$ \\
\hline S. maltophilia R551-3 & Smal_0800 & 366 & 289/367 (78\%) & Smal_0004 & 819 & $705 / 820(85 \%)$ \\
\hline Xylella fastidiosa $9 \mathrm{a} 5 \mathrm{c}$ & XF0343 & 389 & $262 / 381(68 \%)$ & XF0005 & 814 & $632 / 822(76 \%)$ \\
\hline X. fastidiosa Temecula1 & PD1709 & 389 & $262 / 381(68 \%)$ & PD0005 & 814 & $635 / 822(77 \%)$ \\
\hline Clostridium sp. strain M62/1 & CLOM621_09126 & 294 & $202 / 297(68 \%)$ & CLOM621_07162 & 636 & $298 / 562(53 \%)$ \\
\hline Escherichia coli $\mathrm{K}-12$ substrain MG1655 & b0957 & 346 & $48 / 120(40 \%)$ & b3699 & 804 & $497 / 810(61 \%)$ \\
\hline Ralstonia solanacearum GMI1000 & $\mathrm{RSc} 2380$ & 209 & $41 / 108(37 \%)$ & RSc3440 & 842 & $464 / 841(55 \%)$ \\
\hline
\end{tabular}

${ }^{y}$ Amino acid (aa) sequences of XALc_0557 and XALc_0004 of Xanthomonas albilineans were used to search for similar sequences of other bacterial species in the National Center for Biotechnology Information databases using the BLAST algorithm. Orthologs that showed highest similarities to those of $X$. albilineans are cited herein, with the exception of the orthologs in $R$. solanacearum and $E$. coli that are used for comparison.

${ }^{\mathrm{z}}$ Amino acids identity $=$ number of identical amino acids/total number of compared amino acids. 
are phylogenetically relatively close (Pieretti et al. 2009), and because both species are xylem-limited pathogens lacking Hrp T3SS, it seems likely that the XALc_0557 homolog in Xylella fastidiosa is at least essential for xylem colonization in this plant pathogen. Very recently, Chen and associates (2010) reported that a mutation in mopB (equivalent to XALc_0557 in $X$. albilineans) in $X$. campestris pv. campestris Xc17 from Taiwan causes loss of pathogenicity (i.e., capacity to cause symp-
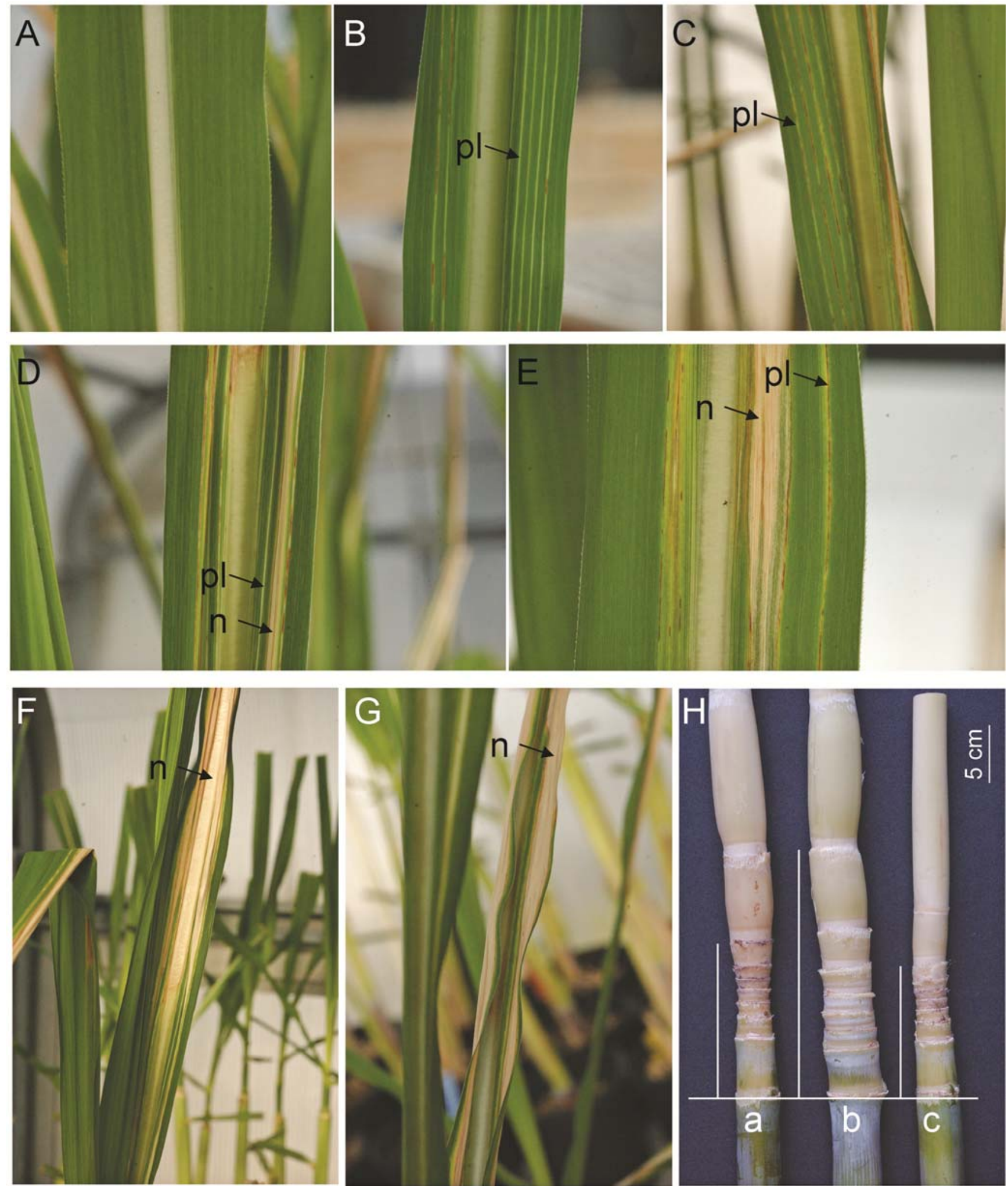

Fig. 5. Leaf scald symptoms caused by Xanthomonas albilineans after inoculation of sugarcane 'CP80-1743'. A, Symptomless leaf inoculated with water. Pencil-line stripes (pl) produced by B, wild-type XaFL07-1 and C, mutant $\triangle a l b X X I$ M8 defective in albicidin production. Pencil-line stripes (pl) and necrosis (n) produced by D, wild-type XaFL07-1 and E, mutant $\triangle a l b X X I$ M8. Severe leaf necrosis (n) produced by F, wild-type XaFL07-1 and G, mutant $\Delta a l b X X I$ M8. All leaves were photographed 1 month after plant inoculation. $\mathbf{H}$, Effect of $X$. albilineans on sugarcane growth: reduced internode size of stalks caused by a, wild-type XaFL07-1 and $\mathbf{c}$, mutant $\triangle a l b X X I$ M8 compared with b, distilled water. White vertical bars represent growth size of seven internodes 2 months after inoculation and removal of leaves. 
toms of cabbage black rot). In Pseudomonas reinekei, a species isolated from an enrichment derived from a polluted stream, outer-membrane protein OprF (an OmpA-family protein) plays an important role under severe nutrient-limiting conditions, during which it acts as a sensing or response protective barrier (Bobadilla Fazzini et al. 2009). XaOmpA1 of X. albilineans is a previously unrecognized and essential pathogenicity factor in $X$. albilineans that could have a similar protective barrier function in the nutrient-poor environment of the xylem. XaOmpA1mutants of $X$. albilineans were affected in vitro in growth rate and in motility and in planta in invasion of the sugarcane stalk xylem. Therefore, XaOmpA1 probably contributes to bacterial fitness. The precise role of this protein in X. albilineans fitness, as well as the possible roles of OmpA proteins in other xanthomonads, is currently under investigation.

\section{MATERIALS AND METHODS}

\section{Bacterial strains and culture conditions.}

Strain XaFL07-1 of X. albilineans was isolated in 2007 from a diseased sugarcane leaf that was sampled at the United States Department of Agriculture Sugarcane Field Station at Canal Point, FL. It was cultured routinely at $30^{\circ} \mathrm{C}$ on MW agar medium containing sucrose $(10 \mathrm{~g})$, peptone $(5 \mathrm{~g}), \mathrm{K}_{2} \mathrm{HPO}_{4}-3 \mathrm{H}_{2} \mathrm{O}$ $(0.50 \mathrm{~g}), \mathrm{MgSO}_{4}-7 \mathrm{H}_{2} \mathrm{O}(0.25 \mathrm{~g}), \mathrm{Na}_{2} \mathrm{SO}_{3}(0.05 \mathrm{~g})$, agar $(15 \mathrm{~g})$, and distilled water (1 liter), $\mathrm{pH} 6.8$ to 7.0. Transposon mutants of XaFL07-1 were cultured on the same medium supplemented with kanamycin at $20 \mathrm{mg} /$ liter. All strains of $X$. albilineans were stored at $-80^{\circ} \mathrm{C}$ as turbid water suspensions and retrieved before transposon mutagenesis or plant inoculation by plating on MW agar medium. E. coli strains were grown on Luria-Bertani (LB) agar or in $\mathrm{LB}$ broth at $37^{\circ} \mathrm{C}$, and were used and stored according to standard protocols (Sambrook et al. 1989).

\section{$X$. albilineans electroporation with a Tn5}

\section{transposase-transposon complex (transposome).}

Two-day-old liquid cultures of $X$. albilineans XaFL07-1 in MW medium were grown at $30^{\circ} \mathrm{C}$ to mid-exponential growth phase $\left(\mathrm{OD}_{600}=0.4\right.$ to 0.5$)$. Cells were incubated on ice for 30

Table 3. Pathogenicity of Xanthomonas albilineans XaFL07-1 and albicidindefective mutant M8 in sugarcane 'CP80-1743' 2 months after inoculation ${ }^{\text {w }}$

\begin{tabular}{lllc}
\hline & \multicolumn{3}{c}{ Pathogenicity parameter $^{\mathrm{x}}$} \\
\cline { 2 - 4 } Strain & \multicolumn{1}{c}{ DS } & \multicolumn{1}{c}{ ESC } & Population $^{\mathbf{y}}$ \\
\hline XaFL07-1 & $5.15(1.200) \mathrm{a}$ & $92(1.307) \mathrm{a}$ & $7.0 \mathrm{a}$ \\
XaFL07-1 $\triangle$ albXXI M8 & $5.15(1.197) \mathrm{a}$ & $91(1.286) \mathrm{a}$ & $6.3 \mathrm{~b}$ \\
Variance analysis ${ }^{\mathrm{z}}$ & & & \\
$\quad$ Strain $F$ & 0.01 & 0.21 & 4.55 \\
Strain $P>F$ & 0.9396 & 0.6503 & 0.0402 \\
\hline
\end{tabular}

${ }^{\mathrm{w}}$ The experiment was set up in a greenhouse in Gainesville (Florida) using a randomized complete block design with six replications of one plant each. Sugarcane 'CP80-1743' was inoculated with each strain at $10^{9}, 10^{8}$, and $10^{7} \mathrm{CFU} / \mathrm{ml}$. No effect of inoculum concentration was found by preliminary variance analysis; therefore, data of each strain were combined for analysis, and values are the mean of 18 plants. Control plants inoculated with distilled water were symptomless and free of the pathogen, and data of these plants were not included in variance analysis.

${ }^{x}$ Disease severity on leaves (DS) and extent of stalk colonization (ESC) values are on a 0-to-6 and 0-to-100 scale, respectively. Means in parentheses are arcsin square root transformed data expressed as proportions (DS/6 and ESC/100). Bacterial population densities are expressed as $\log [(\mathrm{CFU} / \mathrm{g}$ of fresh matter +1$)]$.

${ }^{y}$ Bacterial population density at internode $\mathrm{I}_{+6}$.

${ }^{z}$ Variance analysis of DS and ESC data was performed after arcsin square root transformation of data expressed as proportions (DS/6 and ESC/100). In each column, values followed by the same letter are not significantly different at $P=0.05$ according to the test of StudentNewman-Keuls. min and were collected by centrifugation at $4,000 \times g$ at $4^{\circ} \mathrm{C}$ for $15 \mathrm{~min}$. Cell pellets were washed and resuspended two times, first in $50 \mathrm{ml}$ and then in $25 \mathrm{ml}$ of chilled distilled water. Cell pellets were then resuspended in $1 \mathrm{ml}$ of sterile, ice-cold distilled water, and cells $(50 \mu \mathrm{l})$ were aliquoted and stored at $-80^{\circ} \mathrm{C}$. The EZ-Tn5 <KAN-2>Tnp Transposome complex (Epicentre Biotechnologies, Madison, WI, U.S.A.) was used for transposon mutagenesis of $X$. albilineans. Transposome DNA (20 ng) was electroporated into 40 to $50 \mu \mathrm{l}$ of electrocompetent cells of $X$. albilineans at $18 \mathrm{kV} / \mathrm{cm}$, using an Eppendorf 2510 electroporator (Westbury, NY, U.S.A.). Following electroporation, $1 \mathrm{ml}$ of liquid MW was added to the mix and the culture was grown at $30^{\circ} \mathrm{C}$ for 2 to $3 \mathrm{~h}$ at $120 \mathrm{rpm}$. Then, $50-\mu \mathrm{l}$ aliquots of undiluted and 10x and 100x diluted cultures in liquid MW were spread on MW agar plates containing kanamycin at 20 $\mathrm{mg} /$ liter for selection of transposon mutants.

\section{Cloning, sequencing, and analysis}

of Tn5-tagged regions of $X$. albilineans.

MW liquid medium supplemented with kanamycin (20 $\mathrm{mg} / \mathrm{liter}$ ) was inoculated with cells from Tn5 transformants and incubated with shaking $(120 \mathrm{rpm})$ at $30^{\circ} \mathrm{C}$ for 36 to $48 \mathrm{~h}$. Cultures were centrifuged and total genomic DNA was extracted using the illustra bacteria genomicPrep Mini Spin Kit (GE Healthcare Life Sciences, Piscataway, NJ, U.S.A.), according to the manufacturer's protocol. Plasmid pUC19 (Invitrogen Corporation, Carlsbad, CA, U.S.A.) was used to clone EcoR1-digested genomic DNA fragments. Transformed E. coli cells were spread on LB plates containing kanamycin at 20 to $50 \mathrm{mg} / \mathrm{liter}$ for screening of cloned DNA inserts containing Tn5-tagged regions. Plasmid DNA from kanamycin-resistant clones was sequenced with KAN-2 FP-1 forward primer and KAN-2 RP-1 reverse primer of the transposome kit. All sequencing was performed by the Interdisciplinary Center for Biotechnology Research DNA Sequencing Core Facility at the University of Florida. Sequenced fragments were blasted against the entire genome sequence of $X$. albilineans GPE PC73 from Guadeloupe (Pieretti et al. 2009), using the integrated annotation tool platform at INRA Toulouse (France).

\section{Production of albicidin-defective mutants.}

In order to make a marker-free deletion mutation in albXXI, a gene critical for albicidin biosynthesis (Royer et al. 2004), plasmid pALBXXI-AD, supplied by M. Marguerettaz (Cirad Montpellier, France), was electroporated into electrocompetent cells of $X$. albilineans as described above. This plasmid contained a splice-overlap PCR product that carried both ends (each approximately $1 \mathrm{~kb}$ long) of the target ORF but not the target region $(=a l b X X I)$. This PCR product was cloned into suicide vector pUFR080 (Castaneda et al. 2005), containing two selectable markers and the $s a c B$ gene. Following electroporation, $1 \mathrm{ml}$ of liquid MW medium without sucrose but supplemented with glucose at $10 \mathrm{~g} /$ liter (GW medium) was added to the mix and the culture was grown at $30^{\circ} \mathrm{C}$ for $2.5 \mathrm{~h}$ at $120 \mathrm{rpm}$. Culture aliquots $(50 \mu \mathrm{l})$ were then spread on GW agar plates containing kanamycin at $20 \mathrm{mg} /$ liter. Six-day-old colonies were subcultured on kanamycin-supplemented GW medium, and the resulting culture was streaked on regular MW medium containing sucrose to select for double recombination and deletion of the target gene as described by Castaneda and associates (2005). Colonies that grew on sucrose were analyzed by PCR to verify deletion of albXXI. Absence of albicidin production by selected mutants was verified as described below.

\section{Inoculation of sugarcane with $X$. albilineans.}

All pathogenicity experiments were conducted at the University of Florida under greenhouse conditions using healthy 
plants of sugarcane 'CP80-1743', moderately susceptible to leaf scald. Inoculum of $X$. albilineans was prepared from 2-day-old agar cultures. Except where otherwise stated, sugarcane stalks with at least four to five internodes were inoculated with bacterial suspensions at $10^{8} \mathrm{CFU} / \mathrm{ml}$ in sterile distilled water by a modified decapitation method. In this method, the spindle leaves on a stalk were cut off just below the third visible dewlap with pruning shears and 0.2 to $0.5 \mathrm{ml}$ of inoculum was then deposited onto the cut surface.

\section{Initial screening for reduced pathogenicity of transposon mutant strains.}

In each screening experiment, approximately 200 sugarcane stalks were inoculated, each with a different transposon mutant strain. Leaf scald symptoms (pencil line stripes, chlorosis, and necrosis) were recorded on three to four emerging leaves 1 month after inoculation. Populations of $X$. albilineans were determined in three different stalk locations $\left(\mathrm{I}_{-1}, \mathrm{I}_{+2}\right.$, and $\left.\mathrm{I}_{+5}\right)$ by the stalk blot inoculation technique 2 months after inoculation. Internodes $\mathrm{I}_{0}$ to $\mathrm{I}_{+4}$ corresponded to the location of the five stalk internodes that showed reduced growth after mechanical plant inoculation (cut leaves above the growing point). These internodes were attached to the inoculated leaves and, therefore, were considered to be entry points of the pathogen into the sugarcane stalk.

Stalks were sampled individually and cut at the soil level with pruning shears. The rind of stalk fragments comprising $I_{-1}$, $\mathrm{I}_{+2}$, and $\mathrm{I}_{+5}$ was cleaned with absorbent paper and flamed with alcohol to ensure external sterilization. Each stalk location was then cut transversally, in the middle, with sterile pruning shears. Cut sections were firmly pressed onto two plates, one plate of WCNCB medium and one plate of MW agar medium supplemented with kanamycin at $20 \mathrm{mg} / \mathrm{liter}$, novobiocin at 30 $\mathrm{mg} / \mathrm{liter}$, cycloheximide at $50 \mathrm{mg} / \mathrm{liter}$, and benomyl at 12.5 $\mathrm{mg} /$ liter (WKNCB medium). Pruning shears were flamed with alcohol after each cut. Growth of $X$. albilineans was recorded after 5 days of incubation of agar plates at $30^{\circ} \mathrm{C}$. Pathogen population densities were assessed in each internode using a 0 to- 4 scale, where $0=$ no bacterial colony in the stalk imprint, 1 $=1$ to 10 colonies in the stalk imprint, $2=$ more than 10 colonies or confluent growth of bacteria in less than $25 \%$ of the stalk imprint, $3=$ confluent growth of bacteria in 25 to $75 \%$ of the stalk imprint, and $4=$ confluent growth of bacteria in more than $75 \%$ of the stalk imprint. Only mutant strains that showed scores of 0 to 2 in all three stalk locations were considered for further pathogenicity assays.

\section{Pathogenicity assays.}

In each pathogenicity assay, sugarcane stalks were distributed in the greenhouse using a randomized complete block design with three to eight replications of one plant each. Leaf scald symptoms were recorded on emerging leaves 1 month after inoculation using a symptom severity scale ranging from 0 to 6 , where $0=$ no symptoms, $1=1$ to 5 pencil-line stripes, $2=6$ to 10 pencil-line stripes, $3=$ more than 10 pencil-line stripes, 4 $=$ leaf chlorosis or less than $10 \%$ leaf necrosis, $5=10$ to $50 \%$ leaf necrosis, and $6=51$ to $100 \%$ leaf necrosis. Inoculated stalks were rated individually based on the average score of the three inoculated leaves showing the most severe symptoms. Populations of $X$. albilineans were determined 2 months after inoculation in $10\left(\mathrm{I}_{-4}\right.$ to $\left.\mathrm{I}_{+5}\right)$ to $13\left(\mathrm{I}_{-4}\right.$ to $\left.\mathrm{I}_{+8}\right)$ stalk locations by the stalk blot inoculation technique, as described above. However, in experiments with albicidin-defective mutants, cut sections of stalk internodes were all pressed onto two plates each of WCNCB medium. Pathogen population densities in each internode were assessed using a 0-to-4 scale, as described above. $\mathrm{ESC}$ was expressed as $\mathrm{ESC}=100\left[\left(1 \times N_{1}+2 \times N_{2}+3 \times N_{3}+\right.\right.$ $\left.4 \times N_{4}\right) / 4 \times N_{T}$ ], where $N_{i}=$ number of internodes with score $i$ and $N_{T}=$ total number of internodes.

\section{Determination of bacterial population densities in leaves and stalk internodes.}

Leaf fragments ( 1 to 2 by 2 to $3 \mathrm{~cm}$ ) or internode sections ( 3 to 5 by 4 to $6 \mathrm{~mm}$ ) were weighed and then homogenized in 20-mM Tris-buffered saline buffer $(2.42 \mathrm{~g}$ of Tris, $8 \mathrm{~g}$ of $\mathrm{NaCl}$, and 1,000 $\mathrm{ml}$ of distilled water, $\mathrm{pH} 7.5)$. Homogenized tissues were kept at room temperature for $1 \mathrm{~h}$, then serial diluted for quantification of bacteria. Serial dilutions were plated in triplicate on WCNCB or WKNCB according to the strain of $X$. albilineans. Dilutions were also plated on sucrosepeptone agar (SPA) medium (sucrose at $20 \mathrm{~g} /$ liter, peptone at $5 \mathrm{~g} /$ liter, and agar at $15 \mathrm{~g} /$ liter, $\mathrm{pH} 6.8$ to 7.0 ) when bacteria were to be tested for albicidin production after plant isolation. Bacterial colonies were counted after 5 days of incubation at $30^{\circ} \mathrm{C}$.

\section{In vitro characteristics of $X$. albilineans.}

Growth rate of $X$. albilineans mutants in liquid medium was initially assayed by inoculation of $50 \mathrm{ml}$ of MW medium with $5 \mu \mathrm{l}$ of a bacterial suspension at $10^{9} \mathrm{CFU} / \mathrm{ml}$ of sterile distilled water. Glass flasks were incubated at $30^{\circ} \mathrm{C}$ on an orbital shaker at $100 \mathrm{rpm}$ and $\mathrm{OD}_{600}$ of bacterial suspensions was measured every $8 \mathrm{~h}$ for 12 days using a spectrophotometer. The growth curves of $X$. albilineans and XaOmpA1 mutants M227 and M468 in MW medium and in minimal medium were determined with $50-\mathrm{ml}$ Corning tubes containing $10 \mathrm{ml}$ of medium. Minimal medium contained sucrose $(10 \mathrm{~g})$, L-methionine $(0.1$ g), $\mathrm{K}_{2} \mathrm{HPO}_{4}-3 \mathrm{H}_{2} \mathrm{O}(3 \mathrm{~g}), \mathrm{NaH}_{2} \mathrm{PO}_{4}(1 \mathrm{~g}), \mathrm{NH}_{4} \mathrm{Cl}(1 \mathrm{~g}), \mathrm{MgSO}_{4}-$ $7 \mathrm{H}_{2} \mathrm{O}(0.3 \mathrm{~g})$, and distilled water (1 liter), pH 6.8 to 7.0 (Birch and Patil 1985b). Tubes were inoculated with $100 \mu \mathrm{l}$ of a bacterial suspension at $10^{9} \mathrm{CFU} / \mathrm{ml}$ of sterile distilled water and incubated at $28^{\circ} \mathrm{C}$ on an orbital shaker at $150 \mathrm{rpm}$. Culture samples of $100 \mu \mathrm{l}$ were taken from each tube every day for 7 to 8 days and $\mathrm{OD}_{600}$ of bacterial suspensions was measured using a biophotometer.

Swimming motility was assayed with MW medium and SPA medium, both containing only $0.25 \%$ (wt/vol) agar. Strains were stab inoculated with a sterile loop to the bottom of the petri dish, and all plates were inoculated at least in triplicate. Swim plates were incubated at $30^{\circ} \mathrm{C}$ for 5 to 7 days.

Albicidin production was quantified in vitro by a microbiological assay as described by Birch and Patil (1985b). Briefly, 6- to 8-day-old single colonies of $X$. albilineans on SPA medium were overlaid with $4 \mathrm{ml}$ of a mix containing $2 \mathrm{ml}$ of $1.5 \%$ noble agar (wt/vol) and $2 \mathrm{ml}$ of an E. coli DH5 $\alpha$ suspension $\left(10^{7} \mathrm{CFU} / \mathrm{ml}\right.$ sterile distilled water $)$. The plates were then incubated at $37^{\circ} \mathrm{C}$ for 24 to $48 \mathrm{~h}$. Albicidin production was quantified by calculating the width of the $E$. coli growth inhibition ring as $(D-d) / 2$, where $D=$ diameter of the $E$. coli growth inhibition ring and $d=$ diameter of the $X$. albilineans colony.

\section{Statistical analysis.}

Statistical analyses were performed with SAS (version 9.2; SAS Institute Inc., Cary, NC, U.S.A.).

\section{ACKNOWLEDGMENTS}

We thank J. Shine (Sugar Cane Growers Council, Belle Glade, FL, U.S.A.) and J. Comstock (United States Department of Agriculture, Canal Point, FL, U.S.A.) for supplying healthy sugarcane planting material and sugarcane infected by Xanthomonas albilineans XaFL07-1, M. Marguerettaz (CIRAD, Montpelier, France) for supplying the plasmid construct (pALBXXI-AD) that was used to produce albicidin-deficient mutant isolates of $X$. albilineans, J.-H. Daugrois (CIRAD, Guadeloupe, France) 
for performing statistical analyses of data, and P. Rayside for excellent technical assistance. P. Rott was supported by a Marie Curie Outgoing International Fellowship from the European Commission.

\section{LITERATURE CITED}

Autrey, L. J. C., Saumtally, S., and Dookun, A. 1995. Studies on variation in the leaf scald pathogen, Xanthomonas albilineans. Proc. Int. Soc. Sugar Cane Technol. 21:485-497.

Birch, R. G. 2001. Xanthomonas albilineans and the antipathogenesis approach to disease control. Mol. Plant Pathol. 2:1-11.

Birch, R. G., and Patil, S. S. 1985a. Antibiotic and process for the production thereof. U.S. patent 4,525,354.

Birch, R. G., and Patil, S. S. 1985b. Preliminary characterization of an antibiotic produced by Xanthomonas albilineans which inhibits DNA synthesis in Escherichia coli. J. Gen. Microbiol. 131:1069-1075.

Birch, R. G., and Patil, S. S. 1987a. Correlation between albicidin production and chlorosis induction by Xanthomonas albilineans, the sugarcane leaf scald pathogen. Physiol. Mol. Plant Pathol. 30:199206

Birch, R. G., and Patil, S. S. 1987b. Evidence that an albicidin-like phytotoxin induces chlorosis in sugarcane leaf scald disease by blocking plastid DNA replication. Physiol. Mol. Plant Pathol. 30:207-214.

Blanvillain, S., Meyer, D., Boulanger, A., Lautier, M., Guynet, C., Denancé, N., Vasse, J., Lauber, E., and Arlat, M. 2007. Plant carbohydrate scavenging through TonB-dependent receptors: A feature shared by phytopathogenic and aquatic bacteria. PLoS ONE 2:e224. Published online.

Bobadilla Fazzini, R. A., Bielecka, A., Poucas Quintas A. K., Golyshin P. N., Preto, M. J., Timmis, K. N., and Martins dos Santos, V. A. P. 2009. Bacterial consortium proteomics under 4-chlorosalicylate carbon-limiting conditions. Proteomics 9:2273-2285.

Bruening, G., Civerolo, E., Dandekar, A. M., and Gupta, G. 2004. Exploiting Xylella fastidiosa proteins for Pierce's disease control. Pages 286-289 in: Proceedings, 2004 Pierce's Disease Research Symposium. California Department of Food and Agriculture, San Diego, CA. U.S.A.

Büttner, D., and Bonas, U. 2010. Regulation and secretion of Xanthomonas virulence factors. FEMS (Fed. Eur. Microbiol. Soc.) Microbiol. Rev. 34:107-133.

Castañeda, A., Reddy, J. D., El-Yacoubi, B., and Gabriel, D. W. 2005. Mutagenesis of all eight avr genes in Xanthomonas campestris pv. campestris had no detected effect on pathogenicity, but one avr gene affected race specificity. Mol. Plant-Microbe Interact. 18:1306-1317.

Champoiseau, P., Daugrois, J.-H., Girard, J.-C., Royer, M., and Rott, P. 2006a. Variation in albicidin biosynthesis genes and in pathogenicity of Xanthomonas albilineans, the sugarcane leaf scald pathogen. Phytopathology 96:33-45.

Champoiseau, P., Daugrois J.-H., Pieretti I., Cociancich S., Royer, M., and Rott, P. 2006b. High variation in pathogenicity of genetically closely related strains of Xanthomonas albilineans, the sugarcane leaf scald pathogen, in Guadeloupe. Phytopathology 96:1081-1091.

Chen, Y.-Y., Wu, C.-H., Lin, J.-W., Weng, S.-F., and Tseng, Y.-H. 2010. Mutation of the gene encoding a major outer-membrane protein in Xanthomonas campestris pv. campestris causes pleiotropic effects, including loss of pathogenicity. Microbiology 156:2842-2854.

Daugrois, J.-H., Dumont, V., Champoiseau, P., Costet, L., Boisne-Noc, R., and Rott, P. 2003. Aerial contamination of sugarcane in Guadeloupe by two strains of Xanthomonas albilineans. Eur. J. Plant Pathol. 109:445 458

Davis, M. J., Rott, P., Warmuth, C. J., Chatenet, M., and Baudin, P. 1997. Intraspecific genomic variation within Xanthomonas albilineans, the sugarcane leaf scald pathogen. Phytopathology 87:316-324.

Dunger, G., Relling, V. M., Tondo, M. L., Barreras, M., Ielpi, L., Orellano, E. G., and Ottado, J. 2007. Xanthan is not essential for pathogenicity in citrus canker but contributes to Xanthomonas epiphytic survival. Arch Microbiol. 188:127-135.

Guilhabert, M. R., Hoffman L. M., Mills, D. A., and Kirkpatrick B. C. 2001. Transposon mutagenesis of Xylella fastidiosa by electroporation of Tn5 synaptic complexes. Mol. Plant-Microbe Interact. 14:701-706.

Hashimi, S. M., Wall, M. K., Smith, A. B., Maxwell, A., and Birch, R. G. 2007. The phytotoxin albicidin is a novel inhibitor of DNA gyrase. Antimicrob. Agents Chemother. 51:181-187.

Huang, G. Z., Zhang, L. H., and Birch, R. G. 2000. Albicidin antibiotic and phytotoxin biosynthesis in Xanthomonas albilineans requires a phosphopantetheinyl transferase gene. Gene 258:193-199.

Huerta-Lara, M., Rojas-Martinez, R. I., Bautista Calles, J., Reyes-Lopez, D., Becerril-Herrera, M., Romero-Arenas, O., Franco-Mora, O. Jimenez-Garcia, D., Aragon-Garcia, A., Simon-Baez, A., and GuillenSanchez, D. 2009. Genetic and pathogenic diversity of Xanthomonas albilineans Ashby (Dowson), in Mexico. Res. J. Biol. Sci. 4:312-319.

Jackson, R. W. 2009. Plant pathogenic bacteria. Genomics and Molecular Biology. Caister Academic Press, Norfolk, U.K.

Kingsley, M. T., Gabriel, D. W., Marlow, G. C., and Roberts, P. D. 1993. The ops $X$ locus of Xanthomonas campestris affects host range and biosynthesis of lipopolysaccharide and extracellular polysaccharide. J. Bacteriol. 175:5839-5850.

Klett, P., and Rott, P. 1994. Inoculum sources for the spread of leaf scald disease of sugarcane caused by Xanthomonas albilineans in Guadeloupe. J. Phytopathol. 142:283-291.

Li, Y., Hao, G., Galvani, C. D., Meng, Y., De La Fuente, L., Hoch, H. C., and Burr, T. J. 2007. Type I and type IV pili of Xylella fastidiosa affect twitching motility, biofilm formation and cell-cell aggregation. Microbiology 153:719-726.

Marguerettaz, M., Pieretti, I., Gayral, P., Puig, J., Brin, C., Cociancich, S., Poussier, S., Rott, P., and Royer, M. 2011. Genomic and evolutionary features of the SPI-1 type III secretion system that is present in Xanthomonas albilineans but not essential for xylem colonization and symptom development in sugarcane leaf scald. Mol. Plant-Microbe Interact. 24:246-259.

Mohamed, I. S., Rott, P., Davis, M. J., and Chatenet, M. 1996. Differentiation of Xanthomonas albilineans strains based on multiplication of the pathogen in sugarcane varieties. Proc. Int. Soc. Sugar Cane Technol. 22:486-492.

Patil, P. B., Bogdanove, A. J., and Sonti, R. 2007. The role of horizontal transfer in the evolution of a highly variable lipolysaccharide biosynthesis locus in xanthomonads that infect rice, citrus and crucifers. BMC Evol. Biol. 7:243.

Perez-Donoso, A. G., Sun, Q., Roper, M. C., Greve, L. C., Kirkpatrick, B., and Labavitch, J. M. 2010. Cell wall-degrading enzymes enlarge the pore size of intervessel pit membranes in healthy and Xylella fastidiosainfected grapevines. Plant Physiol. 152:1748-1759.

Pieretti, I., Royer, M., Barbe, V., Carrere, S., Koebnik, R., Cociancich, S. Couloux, A., Darrasse, A., Gouzy, J., Jacques, M.-A., Lauber, E., Manceau, C., Mangenot, S., Poussier, S., Segurens, B., Szurek, B., Verdier, V., Arlat, M., and Rott, P. 2009. The complete genome of Xanthomonas albilineans provides new insights into the reductive genome evolution of the xylem-limited Xanthomonadaceae. BMC Genomics 10:616

Qian, W., Jia, Y., Ren, S.-X., He, Y.-Q., Feng, J.-X., Lu, L.-F., Sun, Q., Ying, G., Tang, D.-J., Tang, H., Wu, W., Hao, P., Wang, L., Jiang, B.-L., Zeng, S., Gu, W.-Y., Lu, G., Rong, L., Tian, Y., Yao, Z., Fu, G., Chen, B., Fang, R., Qiang, B., Chen, Z., Zhao, G.-P., Tang, J.-L., and He, C. 2005. Comparative and functional genomic analyses of the pathogenicity of phytopathogen Xanthomonas campestris pv. campestris. Genome Res. 15:757-767.

Renier, A., Vivien, E., Cociancich, S., Letourmy, P., Perrier, X., Rott, P. C., and Royer, M. 2007. Substrate specificity-conferring regions of the non ribosomal peptide synthase adenylation domains involved in albicidin pathotoxin biosynthesis are highly conserved within the species Xanthomonas albilineans. Appl. Environ. Microbiol. 73:5523-5530.

Rigano, L. A., Siciliano, F., Enrique, R., Sendín, L., Filippone, P., Torres, P. S., Qüesta, J., Dow, J. M., Castagnaro, A. P., Vojnov, A. A., and Marano, M. R. 2007. Biofilm formation, epiphytic fitness, and canker development in Xanthomonas axonopodis pv. citri. Mol. Plant-Microbe Interact. 20:1222-1230

Ristow, P., Bourhy, P., Weykamp da Cruz McBride, F., Pereira Figueira, C., Huerre, M., Ave, P., Saint Girons, I., Ko, A. I., and Picardeau, M. 2007. The OmpA-like protein Loa22 is essential for leptospiral virulence. PloS Pathog. 3:e97.

Rott, P., and Davis, M. J. 2000. Leaf scald. Pages 38-44 in: A Guide to Sugarcane Diseases. P. Rott, R. A. Bailey, J. C. Comstock, B. J. Croft, and A. S. Saumtally, eds. La Librairie du Cirad, Montpellier, France.

Royer, M., Costet, L., Vivien, E., Bes, M., Cousin, A., Pieretti, I., Savin, A., Megessier, S., Viard, M., Frutos, R., Gabriel, D. W., and Rott, P. C. 2004. Albicidin pathotoxin produced by Xanthomonas albilineans is encoded by three large PKS and NRPS genes present in a gene cluster containing also several putative modifying, regulatory and resistance genes. Mol. Plant-Microbe Interact. 17:414-427.

Sambrook, J., Fritsch, E. F., and Maniatis, T. 1989. Molecular Cloning: A Laboratory Manual, 2nd ed. Cold Spring Harbor Laboratory Press, Cold Spring Harbor, NY, U.S.A.

Schauer, K., Rodionov, D. A., and de Reuse, H. 2008. New substrates for TonB-dependent transport: Do we only see the 'tip of the iceberg'? Trends Biochem. Sci. 33:330-338.

Singamsetty, V. K., Wang, Y., Shimada, H., and Prasadarao, N. V. 2008. Outer membrane protein A expression in Enterobacter sakazakii is required to induce microtubule condensation in human brain microvascular endothelial cells for invasion. Microb. Pathog. 45:181-191

Smith, S. G. J., Mahon, V., Lambert, M. A., and Fagan, R. P. 2007. A 
molecular Swiss army knife: OmpA structure, function and expression. FEMS (Fed. Eur. Microbiol. Soc.) Microbiol. Lett. 273:1-11.

Vojnov, A. A., Morais do Amaral, A., Dow, J. M., Castagnaro, A. P., and Marano, M. R. 2010. Bacteria causing important diseases of citrus utilize distinct modes of pathogenesis to attack a common host. Appl. Microbiol. Biotechnol. 87:467-477.

Wang, J. C., So, B. H., Kim, J. H., Park, Y. J., Lee, B. M., and Kang, H. W. 2008. Genome-wide identification of pathogenicity genes in Xanthomonas oryzae pv. oryzae by transposon mutagenesis. Plant Pathol. 57:11361145 .

Wang, L., Makino S., Subedee A., and Bogdanove, A. J. 2007. Novel candidate virulence factors in rice pathogen Xanthomonas oryzae pv. oryzi- cola as revealed by mutational analysis. Appl. Environ. Microbiol. 73(24):8023-8027.

Wang, Y., and Kim, K. S. 2002. Role of OmpA and IbeB in Escherichia coli $\mathrm{K} 1$ invasion of brain microvascular endothelial cells in vitro and in vivo. Pediatr. Res. 51:559-563.

\section{AUTHOR-RECOMMENDED INTERNET RESOURCE}

INRA iANT (integrated ANnotation Tool) complete annotation data for Xanthomonas albilineans GPE PC73 from Guadeloupe: iant.toulouse.inra.fr/bacteria/prj/XANAL/DOC/cgi/index.cgi 